\title{
What is driving the abandonment of villages in the mountains of Southeast China?
}

\author{
Chengchao Wang ${ }^{1,2 *}$, Yaoqi Zhang ${ }^{3}$, Yusheng Yang ${ }^{1,2^{*}}$, QichunYang ${ }^{4}$, Jing Hong ${ }^{2}$ \\ ${ }^{1}$ Key Laboratory for Humid Subtropical Eco-geographical Processes of the Ministry of \\ Education, Fujian Normal University, Fuzhou 350007, P. R. China \\ ${ }^{2}$ College of Geographical Sciences, Fujian Normal University, Fuzhou 350007, P. R. China \\ ${ }^{3}$ School of Forestry \& Wildlife Sciences, Auburn University, AL, 36849, USA \\ ${ }^{4}$ Pacific Northwest National Laboratory, 5825 University Research Court, Suite 1200, \\ College Park, MD 20740, USA
}

\author{
*Corresponding author \\ Chengchao Wang \\ Phone: $+86+591+83465214$; Fax: $+86+591+83465397$ \\ Email:wchc79@163.com \\ Yusheng Yang \\ Phone: $+86+591+83482530 ;$ Fax: $+86+591+83465397$ \\ Email: geoyys@163.com
}

This is the author manuscript accepted for publication and has undergone full peer review but has not been through the copyediting, typesetting, pagination and proofreading process, which may lead to differences between this version and the Version of Record. Please cite this article as doi: $10.1002 / \mathrm{ldr} .3303$

This article is protected by copyright. All rights reserved. 


\begin{abstract}
In recent decades, village abandonment as a result of migration from rural areas constitutes a serious socioeconomic problem in China and many other developing countries. The aim of this study is to identify the drivers of village abandonment in the mountainous areas of Southeast China. Pucheng County was selected as the study case. A conceptual framework for the primary drivers of village abandonment was established to link rural depopulation, farmland abandonment, and house abandonment, which are three integral parts of village abandonment. Results show that the intense rural-urban migration propelled by new urban economic opportunities is the most significant driver of sparse rural population distribution, though this does not usually result in the straightforward abandonment of villages. Instead, the scarcity of public services in mountainous villages is a decisive factor in local resettlement and resultant village abandonment. Limited school access and a demand for high-quality education is the foremost and most immediate motivation for rural-town migration and resettlement in townships, which directly leads to the substantial abandonment of mountainous settlements. Additionally, isolation, higher transportation costs, and nonviability of traditional subsistence agriculture are minor drivers which are interwoven, aggravating the abandonment of remote villages. Our study highlights the aggregated characteristics of village abandonment, heterogeneity of rural emigration and its corresponding primary drivers. These findings will have significant policy implications for decision-makers by helping to identify areas with a high probability of village abandonment, and predict the future magnitude of intra-county migration and subsequent In situ urbanization.
\end{abstract}

\title{
KEYWORDS
}

rural depopulation, land degradation, farmland abandonment, rural poverty, migration 


\section{INTRODUCTION}

Accompanied with intense rural emigration and ageing, the abandonment of villages as a phenomenon has emerged successively in marginal areas of many developed countries and developing countries since the late nineteenth century. This phenomenon usually results in remarkable landscape changes characterized by farmland abandonment, the disappearance of traditional agriculture, reforestation, and even abandoned settlements. These changes have far-reaching impacts on biodiversity and ecosystem recovery (such as soil erosion, land degradation, forest fires, etc.), as well as food security, traditional farming practices and rural livelihoods (Lasanta-Martineza et al., 2005; Baumann et al., 2011; Nunes et al., 2010). More importantly, the process of land degradation and economic marginalization has rarely been interrupted in recent decades according to the experience of developed countries (Vila Subirós et al., 2016). A better understanding of the drivers of village abandonment is a crucial challenge for landscape ecology and land-use science.

Rural depopulation and complete abandonment of villages have been widely reported in industrialized countries, such as the USA, United Kingdom, France, Italy, Spain, Portugal and Japan since the late nineteenth century (Watanabe, 2014). The Mediterranean region, in particular, experienced drastic population loss and massive village abandonment, especially in marginal areas in the 1950s and 1960s (Ruecker et al., 1998; Di Figlia, 2016; Vila Subirós et al., 2016). However, the phenomenon has occurred less in developing countries. More recently it was sporadically reported in some developing countries, such as Macedonia, Bulgaria, Serbia and Brazil (Macdonald \& Winklerprins, 2014), where villages with less than 
50 inhabitants residing locally were defined as abandoned. The abandonment of villages will be prevalent in developing countries in the future, based on Western countries' experience, which will have severe impacts on land degradation and rural poverty. Thus, it is urgent to attain a thorough understanding of the driving forces of village abandonment in currently developing countries to alleviate the projected problems.

Village abandonment characterized by severe rural depopulation, farmland abandonment, partly discarded houses and degraded infrastructure may well evolve into entirely abandoned settlements (Figure1). Existing research has shown that the manifestation of this abandonment differed substantially, within and among countries (Müller et al., 2009), raising the question about the drivers of these patterns. Generally, the driving forces of the individual dimensions of village abandonment have been studied separately owing to the research priorities of different disciplines. Most empirical research in landscape ecology and land-use science focused on the driving forces of agricultural land abandonment. Biophysical, socioeconomic and political factors were considered as the primary causes of land abandonment (Baumann et al., 2011; Khanal \&Watanabe, 2006). Researches in demography and population geography have generally focused on the driving forces of rural emigration and related depopulation. A famous macro explanation of migration is Lewis' dual economy model, which attributes the rural-urban migration to the economic and wage gap between urban and rural areas (Lewis, 1954). Te 'theory of pull-push' was proposed to state the driving forces of migration, which categorized factors that affect migration as 'push' factors in the area of origin, 'pull' factors in the area of destination, and intervening obstacles (Lee, 1966). The new economics of migration assumes that people migrate not only to gain higher wages but also to manage risk and gain access to capital that will enable them to finance consumer purchases and production activities (Stark, 1991). Research in architecture and sustainability science reported that agricultural mechanization, the transformation of agricultural production and urban attraction resulted in the abandonment of many rural houses (Fuentes et al., 2010; Torreggiani \& Tassinari, 2012). Studies have highlighted that drastic environmental changes were the leading cause of rural house abandonment in many regions (McLeman, 2011). The above studies elucidated the driving forces of farmland abandonment, rural depopulation and rural house abandonment respectively, but they failed to integrate three manifestations of village abandonment as a whole. In fact, farmland abandonment, rural depopulation and house 
abandonment are interlinked, with the complete abandonment of villages as an extreme-case status.

\section{Figure 1 here}

Rural emigration driven by rapid industrialization and urbanization has been prevalent since the 1980s in China. It was reported that there were approximately 277.47 million rural migrant workers (Nong min gong) in cities in 2015. These were primarily younger and middle-aged labourers, with age 16 40 cohort and age 41 50 cohort accounting for 55.2\% and 26.9\% respectively (National Bureau of Statistics of China, 2016). Emigration and its impact on fertility and ageing resulted in remarkable rural depopulation in China. The extreme outcomes of rural depopulation, including the abandonment of villages, are also emerging in China, especially in remote mountainous villages. It was reported that the number of unincorporated hamlets (ziran cun) in China decreased from 3.63 million in 2000 to 2.71 million in 2010, with 0.92 million villages abandoned and, on average, 250 villages lost every day during the decade (Zhang, 2016). Among them, the majority belonged to spontaneous abandonment. However, research on this phenomenon is scarce. Most previous studies of rural-urban migration focused on urban destinations. While internal rural-town and rural-rural migration were neglected. Minimal research has been concerned with some traits of the abandonment of villages. For example, some researchers found that rapid industrialization and urbanization had produced a unique phenomenon of 'village-hollowing', which simultaneously showed the interior ruin and outer development of villages (Long et al., 2012).

In this article, our major goal is to analyse the biophysical, social, and economic drivers of the abandonment of villages in China based on a case study in Pucheng County. The permanent rural-town migration with resettlement and demand for education has been highlighted.

\section{MATERIALS AND METHODS}

\subsection{Study area}

\subsubsection{General information}


Pucheng County is located in the northern Fujian Province of Southeast China $\left(27^{\circ} 32^{\prime} \sim 28^{\circ} 19^{\prime}\right.$ $\mathrm{N}, 118^{\circ} 11^{\prime} \sim 118^{\circ} 49^{\prime} \mathrm{E}$ ) at the north-western extension of the Wuyi Mountains and northeastern extension of the Xianxia Mountainsand with an area of about 3,383 $\mathrm{km}^{2}$ (Figure 2). It is ringed on three sides (north, east, west) by mountains, and is relatively flat in south and central areas. The uplands are the principal geomorphic type, which accounts for $79.8 \%$ of the area. Farmland is relatively limited and accounted for only 11.87\% of Pucheng in 2007 (0.12 ha per farmer). Steeply mountainous terrain facilitates the formation of numerous and scattered unincorporated villages (ziran cun). Each village generally contains several to twenty or thirty households. The county has a humid, mid-subtropical monsoon climate with high mean precipitation $\left(1,780 \mathrm{~mm}_{\text {year }}{ }^{-1}\right)$ and warm annual temperature $\left(17.4^{\circ} \mathrm{C}_{\text {year }}{ }^{-1}\right)$. A rainy climate and steep terrain make mountainous villages prone to frequent natural disasters, such as flooding, landslides, debris flow, that result in severe economic losses every year.

\section{Figure 2 here}

\subsubsection{Migration typologies}

Rural-town migration usually concentrated in three different destination areas: (i) Government-sponsored resettlement communities, i.e. a social and spatial unit within the town that has been a unit of migrant organization. Only households or hamlets that meet at least one criterion (threatened by natural disasters, or far remote villages) could resettle in these new communities. Local governments (esp. township governments) often appropriated new land close to townships for building some entirely emigrant communities. Households within the same village all move together to another location, and households from several original villages constitute the new resettlement community. (ii) Newly built villages, i.e. a village collective organization appropriated some land close to the original administrative village for construction in the name of village merging (esp. the scattered and remotely unincorporated villages) or new village construction. The homestead of the new community is expensive because it is usually close to townships and has better transportation. Only relatively wealthy households from the original village and other adjacent villages could pay the expensive land and building costs. (iii) Commercial residential buildings in township. Everyone can buy the apartment if you can afford it. For many commercial residential buildings with relatively low prices, buyers are mainly from remote villages. 
Table 1 here

\subsection{A new conceptual framework}

The abandonment of villages is an integration of three processes: rural depopulation, farmland abandonment and house abandonment. Each usually has a series of driving factors. For rural depopulation, previous research showed that the causes for rural emigration and depopulation are multidimensional. Economic, social, environmental and political factors were frequently discussed (Black et al., 2011). The causes for farmland abandonment are also multidimensional, and they are usually grouped into natural constraints, socioeconomic factors, and unsuitable institutions (Benayas et al., 2007). While the causes of house abandonment mainly include disadvantageous environment and natural disasters, exhaustion of natural resources, low productivity and poverty (Vila Subirós et al., 2016). In this study, the 'theory of pull-push' was referred to construct a new conceptual framework to elucidate the drivers of the abandonment of villages. Figure 3 summarizes this framework, which has three components:

(1) New economic opportunities derived from urbanization and industrialization in big cities and coastal areas of China (including off-farm employment opportunities, higher incomes, better environments, etc.) are important 'pull' forces, which drive the first wave of rural emigration to external destinations outside the county and cause subsequent rural depopulation.

(2) In situ urbanization and related rural industrialization, government-sponsored resettlement projects, school closure and concentration of rural primary education are important 'pull' forces, which drive the second wave of rural emigration to local townships within the county and cause subsequent house abandonment.

(3) Unsuitable environmental conditions, poor accessibility, and non-viability of traditional subsistence agriculture are the primary 'push' forces, which drive the rural emigration and farmland abandonment.

It should be noted that the above three processes usually interact with each other. For example, rural depopulation driven by urbanization and industrialization of outer regions often results in a remarkable loss of primary school students and an increase in poor quality education, which promotes the second wave of rural emigration. Rural depopulation also 
results in the scarcity of agricultural labour, which is an important driver of farmland abandonment (Figure 3).

\section{Figure 3 here}

\subsection{Data collection and methods}

Two kinds of data were collected: statistical data and a field survey in two towns (Xianyang, Shanxia) featuring the severe abandonment of villages. All second-hand data was collected from governmental departments, such as the Bureau of Statistics, Bureau of Agriculture, Education Bureau, and the Health and Family Planning Commission of Pucheng County. The data mainly includes two parts: one is the distribution of primary school students between the county seat and other townships, between township central primary schools and other village primary schools; the other is the migration and economic data derived from the Sixth Population Census Reports, Statistics Yearbook, and Statistics and Bulletin of the Migration of Pucheng County. Subsequently, a field survey was conducted in five resettlement communities whose primary residents (about $80-90 \%$ ) came from remote mountainous villages (Table 1, Figure 2). The survey's objective is to summarize the motivation of rural households emigrating from mountainous villages. Before data collection, we interviewed six administrative leaders responsible for rural development, to obtain a comprehensive understanding of rural depopulation, the intensity of village abandonment, and to choose typical survey sites. Furthermore, we also interviewed ten village/community leaders to understand the history of emigration of investigated villages. We then interviewed rural households with questionnaires from June 2, 2016, to August 17, 2016, in resettlement communities.

The sampling process is as follows. First, we gained the lists of all community households from the local governments and encoded them. Second, $10 \%$ of these households were selected for interviews. Third, some households were added or deleted from the sampling lists according to the community size, interviewee heterogeneity, residential population, and survey costs. For example, many households of Zhangjialing village were busy with decorating their houses or did not use their houses during our survey, which led to ralatively low sampling rate. Our survey sample size is adequate, considering the lower heterogeneity in 
interviewees and survey questions. Finally, 83 households from five communities were randomly selected and investigated (Table 1).

The questionnaire included 23 questions in three sections focusing on the household-level: (i) basic information, including demographic characteristics, original village location, and resettlement costs; (ii) migrating motivation, mainly including 'pull' factors of migration (road conditions, distance to towns, education and healthcare service, rural employment), 'push' factors of migration (education and healthcare service, communication conditions, employment opportunities); (iii) livelihood changes after resettlement, including land use change, crop and forestry production, changes in income quantity and composition; (iv) farmland abandonment and harassment by wild animals. Finally, we gained 83 effective questionnaires (Table 1). We input all of the questionnaire and second-hand data into our computers to explore the drivers of village abandonment.

\section{RESULTS AND DISCUSSION}

\subsection{Heavy out-migration driven mainly by new economic opportunities in cities}

Our field survey and in-depth interviews showed that large economic disparities between urban and rural areas and the loosening of restrictions on rural-urban migration have propelled tremendous rural-urban migration, especially from less-developed inland to more developed coastal regions since the 1990s. According to the Fourth, Fifth and Sixth National Population Census of China conducted in 1990, 2000, and 2010, respectively, the number of out-migrants was just 6,600 in 1990 in Pucheng County. But the number increased to 104,000 in 2000 and 135,000 in 2010. Correspondingly, the percentage of migrants to total number of registered population increased from $1.71 \%$ in 1990 to $25.83 \%$ and $31.33 \%$ in 2000 and 2010, respectively. This tremendous rural-to-urban migration has usually brought about intense rural depopulation, and population ageing, especially in remote villages. In a word, heavy rural exodus driven by new economic opportunities in external cities is the fundamental cause of rural depopulation and is the macro context of village abandonment (Figure 3). Our study showed that $64 \%$ of migrants in Pucheng County in 2010 were economic migrants who foremost sought better fortunes in external county regions (Figure 4). Moreover, rural-urban migration affected farmland abandonment and house abandonment indirectly by decreasing the agricultural labour supply, decreasing the number of school-age children, and providing remittances for resettlement, etc. (Figure 3).

Our results found that the remarkable disparity in economic opportunities between origins 
and destinations is the primary cause of rural emigration and depopulation, which, to a certain extent, promotes the abandonment of farms and homes. The results were similar to those of many developed countries in the nineteenth and twentieth century (Hutchinson, 1953; Collantes \& Pinilla, 2004) and that of Japan since the late 1960s (Irving, 1996). These results are also consistent with other research in China (Zhu, 2007; Wang et al., 2011; Qin \& Liao, 2016) and other developing countries (Rudel et al., 2005). Even in some of the least developed countries, the phenomenon has emerged (Chidi, 2015).

\section{Figure 4 here}

\subsection{Rural-town migration driven by a demand for education}

Under rapid industrialization and urbanization in coastal areas and persistent rural poverty in the past two decades, a huge wave of rural-urban migration driven by new economic opportunities in cities has led to a sharp decline in the number of children in underdeveloped regions (Figure 3, Figure 4). Many rural children have followed their parents to cities. Considering the intensity of the rural emigration of Pucheng County, it is estimated that the emigrating primary school-age children (aged 6-11) to external regions outside the county may account for aboutone third of the total. The vast loss of school-age children first led to the quantity of students in many mountainous villages being below the minimum threshold of maintaining a primary school (Figure 3). Under these circumstances, China's State Council issued the instructive document named the Decision of the China's State Council on Basic Education Reform and Development in 2001 to optimize educational resources, which proposed the appropriate closure and merging of rural schools to substitute for the traditional pattern of 'one village with one primary school'. A multitude of closure and merging of rural schools has taken place since 2001. This concentration of education is characterized by gathering rural students into township schools and the closure or consolidation of village schools. The majority of rural primary schools, especially in remote mountainous village schools, were closed and merged into township schools (Table 2). Generally, every town has a Township Central Primary School, which has better teachers, sufficient educational funds and better teaching conditions. As shown in Table 2, the urbanization and centralization of rural elementary education was prominent during 1986-2015. The number of primary schools (including Grade 1 to 6) and rural primary schools (including Grade 1 to 3 ) decreased by 
$84.1 \%$ and $83.1 \%$ respectively, which was tremendously higher than that of the total pupils (44.13\%). The results implied that pupils transferred in increased numbers to township primary schools. The average number of pupils studying at township central primary schools accounted for $12.08 \%$ and $71.65 \%$ of the total pupils in 1986 and 2015, respectively, increasing by $57.51 \%$ (Table 2). Moreover, the degree of urbanization and centralization of rural elementary education is higher in remote areas, such as Fengxi Town and Guanlu Town.

As a result, the urbanization of countryside education has brought about the second wave of rural-town migration driven by a demand for education (Figure 3, Figure 4). For the whole county, our study showed that $24 \%$ of migrants in Pucheng County in 2010 belonged to educational migrants seeking better child education within the county as the foremost reason for migration (Figure 4). On the one hand, closure of village primary schools has propelled remarkable rural-town migration. Owing to the large-scale closure of rural primary schools, the majority of elementary school students coming from remote villages have to travel up to $25 \mathrm{~km}$ to faraway schools. To better care for school-aged children, many wealthy rural households have strived to move out of remote villages and have resettled in towns. Our field survey proved that the primary reason for rural-town migration was a demand for children's education, which accounted for $65.1 \%$ (Table 3 ). The demand for children's education has turned into the foremost cause of permanent rural-town settlement. It is higher in Xiaoxi (75.0\%) and Xingfuli (100\%). Except for the wealthier households resettling in towns, most rural parents were forced to rent houses close to their children's schools to accompany their children (Table 4). Our survey showed that $55.4 \%$ of households reported that they arranged for at least one adult to accompany their children in towns before resettlement.

On the other hand, demands for high-quality education have also promoted further ruraltown migration. The education system in China is typically hierarchical and differently ranked schools could gain associated educational resources. Due to poor living and working conditions, it was difficult for village primary schools to attract new graduates of colleges during the past three decades. Moreover, some experienced and outstanding teachers transferred to township schools during the wave of closure and the merging of schools in the past decade. Thus, these factors contributed to the deterioration of village teachers' resources. The remaining teachers of village schools are mostly original village-sponsored teachers. These village teachers generally have contributed to rural compulsory education in the past thirty years. However, their teaching techniques and knowledge could not satisfy the higher 
expectations of parents' today. Their elderly age, poor education background and scarce training made them unqualified for teaching new curricula (such as English, Music, Arts). The tremendous disparity in rural and town/urban education has gradually formed and intensified. A recent study showed that academic performance in three subjects (Chinese, mathematics and English) of students in village primary schools was much poorer than that of township or county seat primary schools (Wu \& Qin, 2017). Consequently, many parents moved to towns to let their children acquire better education even if there were still elementary schools in their original villages. Data showed that there were only seven village primary schools in Xianyang Town in 2015. These villages are usually big villages with populations of 1,600-3,000, which should ordinarily have more local primary school-aged children. But the number of students in each village primary school was all below 100 which was the minimum number for maintaining a complete primary school (including Grade 1 to 6). Each of the four primary schools has less than 20 pupils. Our survey proved that most schoolaged children were transferred to Xianyang Township Central Primary School to gain a better education, though there were village schools.

The results are generally consistent with a few studies in developing countries that identified access to education as a critical motive for rural-urban migration (Parry et al., 2010; Child set al., 2014), but differences were apparent in migrating destinations and out-migration intensity. The migrants of previous studies usually migrated from remote mountainous villages directly to large cities, which was similar to the first wave of rural-urban migration we discussed. Our results were also consistent with some education-driven rural emigration reported in Japan, where the closure of town high schools has driven the migration (Okubo et al., 2015).

Table 2 here

Table 3 here

Table 4 here

\subsection{Isolation and higher transportation costs}

Isolation or remoteness (the inverse of accessibility) usually means a difficulty in accessing external influences and opportunities. It is generally measured by commuting distance to the nearest township and distance to county seat/ large cities. A long distance to large cities or 
townships indicated higher transportation costs for the provision of public services and input/output goods. Our survey showed that the average distance from the original villages to the nearest township in Xiang'an, Zhangjialing, Liancun, Xingfuli, and Xiaoxi community was $18 \mathrm{~km}, 13 \mathrm{~km}, 14 \mathrm{~km}, 17 \mathrm{~km}$, and $9 \mathrm{~km}$, respectively (Table 1). While the average distance to county seat was 33 km, 27 km, 36 km, 29 km and 48 km, respectively. All respondents' original villages have no schools and the nearest primary school is located in townships. The isolation also affected other public goods supply, especially road and public transportation. Results of our questionnaires showed that $48.2 \%$ of respondents reported that there were no concrete roads directly leading to their hamlets and $84.3 \%$ of respondents claimed no public buses commuted from townships to their remote villages. Moreover, $20.5 \%$ of interviewees listed poor rural transportation as the primary driver of resettlement (Table 1), which accounted for $15.8 \%, 36.0 \%, 20.0 \%$ and $10.0 \%$ for Xiang'an, Zhangjialing, Liancun and Xiaoxi community respectively. Furthermore, higher transportation costs derived from isolation not only depended on physical distance to markets, but also road quality. Especially in mountainous hamlets located on steep slopes, the labour costs of moving materials and products from flat roads (suitable for vehicles) to pinnacle houses through steep stone roads were very higher. All transportation from village gates to houses relied on carrying goods with shoulders, while modern vehicles can not function in these locations (Figure 5) .

Rural emigration provided more pristine space for wildlife, leading to rapid growth of wild animals, which resulted in more harassment by wild animals. Our survey showed that $61.4 \%$ of respondents reported that there was an increase in wild animals in their mountain villages during the past five years. $69.90 \%$ of respondents reported that they abandoned some farmland. Among them, $55.2 \%$ of respondents listed poor accessibility as the primary cause for farmland abandonment, compared with $17.2 \%$ listing lower farm income and non-viability, $15.5 \%$ harassment of wild animals, $5.2 \%$ poor soil fertility or irrigation conditions, and $6.9 \%$ listing other causes. Consequently, poor accessibility is the first cause for farmland abandonment in remote villages. Meanwhile, poor accessibility would also boost rural depopulation and house abandonment through decreased agricultural productivity and the supply of public services discussed above.

Our conclusion that village abandonment is related to isolation corroborates the results of previous studies (Collantes \& Pinilla, 2004; Müller et al., 2008; Díazet al., 2011). Research based on mountainous areas in northern Vietnam found that poor village accessibility had a 
significant impact on farmland abandonment (Castella et al., 2005). In Japan, tremendous 'marginal settlements' are on the edge of extinction because the poor vitality and low population density have led to underdeveloped public and commercial services (Feldhoff, 2013).

\section{Figure 5 here}

\subsection{The non-viability of traditional subsistence agriculture}

Owing to high elevation and steep topography, the number of large plots of flat farmland was just one third of the total farmland in the studied regions. But the fragmented, steep, infertile farmland (such as mountain ridged fields and terraces), which was not suitable for agricultural mechanization, became the principal land type. Our survey proved that $79.5 \%$ of respondents reported their farmland was unsuitable for large agricultural machines (such as large tractors and combine harvesters) due to land fragmentation (Table 5). Small and highly fragmented landholdings on steep slopes have constrained the use of modern labour-saving agricultural machines invented primarily for plains areas. In addition, other unsuitable conditions, such as natural disasters, ageing labour and poor technology, aggravated its disadvantages. Therefore, agricultural systems in mountainous areas were faced with survival problems, as a result of increased specialization in other areas that enjoyed a favourable resource endowment and better supporting facilities. Accordingly, some external shocks, such as increasing costs and decreasing price, would undermine the viability of agriculture and lead to extensive land abandonment (Figure 3). According to our survey, 57.8\% of respondents abandoned the majority of their land and only cultivated the high-quality land alone or by friends and relatives. Only $9.6 \%$ of respondents abandoned their total cropland (Table 5). Lower farm income and non-viability of traditionally small farms accounted for $17.2 \%$ of the causes for abandonment, which was the second highest cause of farmland abandonment. Along with drastic competition with urban off-farm sectors and agricultural production in plains, the nonviability of traditional agricultural production based on self-sufficiency led to farmland abandonment in remote villages.

In summary, our study shows that the non-viability of traditional subsistence agriculture is the second cause of farmland abandonment in remote villages. This further aggravated rural depopulation and ageing. Rural villages may be on the edge of complete abandonment when 
depopulation and ageing exceed a certain threshold. The results are consistent with previous studies on agricultural marginalization in remote uplands (Collantes \& Pinilla, 2004; Khanal $\&$ Watanabe, 2006). The results are also generally consistent with Forest Transition Theory, which proposes that agricultural intensification will be concentrated in the most suitable regions due to economic development and industrialization. Marginal fields will be abandoned due to non-viability (Rudel et al., 2005).

Table 5 here

\section{CONCLUSIONS AND FUTURE WORK}

Our results show that in addition to the previously reported rural emigration to cities propelled by increasing urban economic opportunities, scarcity of public services, reduced labour productivity, and higher transportation costs are important drivers of village abandonment. New economic opportunity in cities is the leading driver of rural depopulation. However, the demand for education and associated rural-town migration is the most immediate cause of the abandonment of villages. Access to education emerged as a crucial factor in driving the abandonment of remotely mountainous settlements and out-migration to local townships. Due to similar patterns of industrialization, urbanization, and population migration, what is currently occurring in China would likely emerge in the future in other developing countries in Southeast Asia, South Asia and South America. Additionally, ruraltown migration is a trend that has received little attention, and together with rural-urban, cyclical, and seasonal migration, is in need of more research to understand the drivers of the abandonment of remote rural settlements and the growth of local towns. Understanding the drivers of the abandonment of villages can be used to predict future changes in agricultural landscapes, flows and values of ecosystem services, population distribution, spatial characteristics of food production and urbanization patterns in China and other developing countries. This research is providing general insights into the problem, but it generates many new questions, such as the process, mechanism, spatial difference, and ecological effects of the abandonment of villages, which need more in-depth surveys and quantitative studies in the future. 


\section{ACKNOWLEDGEMENTS}

The study was funded by the National Natural Science Foundation of China (Grant no. 41371527) and Soft Science Project of Fujian Province (Grant no. 2018R0031). We thank local governments of Pucheng County for providing valuable data and help in our field work.

\section{REFERENCES}

Baumann, M., Kuemmerle, T., Elbakidze, M., Ozdogan, M., Radeloff, V.C., Keuler, N.S., ... Hostert, P. (2011). Patterns and drivers of post-socialist farmland abandonment in Western Ukraine. Land Use Policy, 28(3), 552-562. https://doi.org/10.1016/ j. landusepol. 2010. 11.003

Benayas, J.R., Martins, A., Nicolau, J.M., \& Schulz, J.J. (2007). Abandonment of agricultural land: an overview of drivers and consequences. $C A B$ reviews: Perspectives in agriculture, veterinary science nutrition and natural resources, 2(57), 1-14. https://doi.org/10.1079/PAVSNNR20072057

Black, R., Adger, W.N., Arnell, N.W., Dercon, S., Geddes, A., \& Thomas, D. (2011). The effect of environmental change on human migration. Global Environmental Change, 21, S3-S11. https://doi.org/10.1016/j.gloenvcha.2011.10.001

Castella, J.C., Manh, P.H., Kam, S.P., Villano, L., \& Tronche, N.R. (2005). Analysis of village accessibility and its impact on land use dynamics in a mountainous province of northern Vietnam. Applied Geography, 25(4), 308-326. https://doi.org/10.1016/j.apgeog.2005.07.003

Chidi, C.L. (2015). Depopulation and rural land abandonment in the hills of Nepal. SSARSC Int J Geo Science Geo Info, 3(1), 1-7.

Collantes, F., \& Pinilla, V. (2004). Extreme depopulation in the Spanish rural mountain areas: a case study of Aragon in the nineteenth and twentieth centuries. Rural History, 15(2), 149-166. https://doi.org/10.1017/s095679- 3304001219

Díaz, G.I., Nahuelhual, L., Echeverría, C., \& Marí, S. (2011). Drivers of land abandonment in Southern Chile and implications for landscape planning. Landscape and Urban Planning, 99(3), 207-217. https://doi.org/10.1016/j.landurbplan.2010.11.005

Di Figlia, L. (2016). Turnaround: abandoned villages, from discarded elements of modern Italian society to possible resources. International Planning Studies, 21, 278-297. https://doi.org/10.1080/13563475.2016.1186530

Feldhoff, T. (2013). Shrinking communities in Japan: Community ownership of assets as a development potential for rural Japan?. Urban Design International, 18(1), 99-109. https://doi.org/10.1057/udi.2012.26

Fuentes, J.M., Gallego, E., García, A.I., \& Ayuga, F. (2010). New uses for old traditional farm buildings: The case of the underground wine cellars in Spain. Land Use Policy, 27(3), 738-748. https://doi.org/10.1016/j.landusepol.2009.10.002 
Hutchinson, B. (1953). Depopulation and rural life in Scotland. Nature, 171, 643-644. https://doi.org/10.1038/171643

Irving, R.T.A. (1996). The problem of severe rural depopulation in Japan: from retrospective countermeasure to a forward looking rural policy. Journal of Policy Studies, 1, 41-54.

Khanal, N.R., \& Watanabe, T. (2006). Abandonment of agricultural land and its consequences: A case study in the Sikles area, Gandaki Basin, Nepal Himalaya. Mountain Research and Development, 26(1), 32-40. https://doi.org/10.1111/j.1931-0846.2014.12027.x

Lasanta-Martineza, T., Vicente-Serrano, S.M., \& Cuadrat-Prats, J.M. (2005). Mountain Mediterranean landscape evolution caused by the abandonment of traditional primary activities: a study of the Spanish Central Pyrenees. Applied Geography, 25(1), 47-65. https://doi.org/10.1016 /j.apgeog.2004.11.001

Lee, E.S. (1966). A theory of migration. Demography, 3(1), 47-57. https://doi.org/10.2307/2060063

Lewis, W.A. (1954). Economic development with unlimited supplies of labor. The Manchester School of Economic and Social Studies, 22(1), 139-191. https://doi.org/ 10.1111/j.14679957.1954.tb00021.x

Long, H., Li, Y., Liu, Y., Woods, M., \& Zou, J. (2012). Accelerated restructuring in rural China fueled by 'increasing vs. decreasing balance' land-use policy for dealing with hollowed villages. Land Use Policy, 29, 11-22. https://doi.org/10.1016/j.landusepol.2011. 04.003

Macdonald, T., \& Winklerprins, A.M.G.A. (2014). Searching for a better life: Peri-urban migration in western Para State, Brazil. Geographical Review, 104(3),294-309. https://doi.org/10.1111/j.19310846. 2014. 12027.x

McLeman, R.A. (2011). Settlement abandonment in the context of global environmental change. Global Environmental Change, 21, S108-S120.

https://doi.org/10.1016/j.gloenvcha.2011.08.004

Müller, D., \& Munroe, D.K. (2008). Changing rural landscapes in Albania: croplandabandonment and forest clearing in the postsocialist transition. Annals of the Association of American Geographers, 98(4), 855-876. https://doi.org/10.1080/00045600-802262323.

National Bureau of Statistics of People's Republic of China. (2016). Statistical Yearbook of China 2016. Beijing: China Statistical Publisher House, China (In Chinese).

Nunes, A.N., Coelho, C.O.A., De Almeida, A.C., \& Figueigedo, A. (2010). Soil erosion and hydrological response to land abandonment in a central inland area of Portugal. Land Degradation\& Development, 21(3), 260-273. https://doi.org/10.1002/ldr.973.

Okubo, M., Mohammed, A.J., \& Inoue, M. (2015). Out-migrants and Local Institutions: Case Study of a Depopulated Mountain Village in Japan. Asian Culture and History, 8(1), 1-9. https://doi.org/10.5539/ach.v8n1p1 
Parry, L., Day, B., Amaral, S., \& Peres, C.A. (2010). Drivers of rural exodus from Amazonian headwaters. Population and Environment, 32(2-3), 137-176. https://doi.org/10.1007/s11111-0100127-8

Qin, H., \& Liao, T.F. (2016). Labor out-migration and agricultural change in rural China: A systematic review and meta-analysis. Journal of Rural Studies, 47, 533-541. https://doi.org/10.1016/j. jrurstud.2016.06.020

Rudel, T.K., Coomes, O.T., Moran, E., Achard, F., Angelsen, A., Xu, J., ...Lambin, E. (2005). Forest transitions:Towards a global understanding of land use change. Global environmental change, 15(1), 23-31. https://doi.org/10.1016/j.gloenvcha.2004.11.001s 13593-013-0183-4

Ruecker, G., Schad, P., Alcubilla, M.M., \& Ferrer, C. (1998). Natural regeneration of degraded soils and site changes on abandoned agricultural terraces in Mediterranean Spain. Land Degradation \& Development, 9, 179-188. https://doi.org/ 10.1002/(SICI)1099-145X(199803/04)9:2<179::AIDLDR276>3.0.CO;2-R.

Stark, O. (1991). The Migration of the Labor. Cambridge: Harvard University Press, Massachusetts USA.

Torreggiani, D., \& Tassinari, P. (2012). Landscape quality of farm buildings: The evolution of the design approach in Italy. Journal of Cultural Heritage, 13(1), 59-68. https://doi.org/ 10.1016/j.culher.2011.06.002

Vila Subirós, J., Rodríguez-Carreras, R., Varga, D., Úbeda, X., Asperó, F., Llausàs, A., \& Outeiro, L. (2016). Stakeholder perceptions of landscape changes in the Mediterranean mountains of the North

- Eastern Iberian Peninsula. Land Degradation \& Development, 27(5), 1354-1365. https://doi.org/10.1002/ldr.2337.

Wang, C., Yang, Y., \& Zhang, Y. (2011). Economic development, rural livelihoods, and ecological restoration: evidence from China. Ambio, 40(1), 78-87. https://doi.org/10.1007/s13280-010-00935

Watanabe, S. (2014). Historical praxis in a depopulating and aging village in Japan: some controversial issues of the postwar economic growth and its consequence. Journal of rural studies (Osaka), 21(1), 14-25. https://doi.org/ 10.9747/jars.21.1_14

Wu, Z., \& Qin, Y. (2017). Rural education development in China: An annual report. Beijing: Bejing Normal University Press, China (In Chinese).

Zhang, L.Z. (2016). The Disappeared villages. New Industrial Economy, 4, 9 (In Chinese).

Zhu, Y. (2007). China's floating population and their settlement intention in the cities: Beyond the Hukou reform. Habitat International, 31(1), 65-76. https://doi.org/10.1016/j.habitatint.2006.04.002 


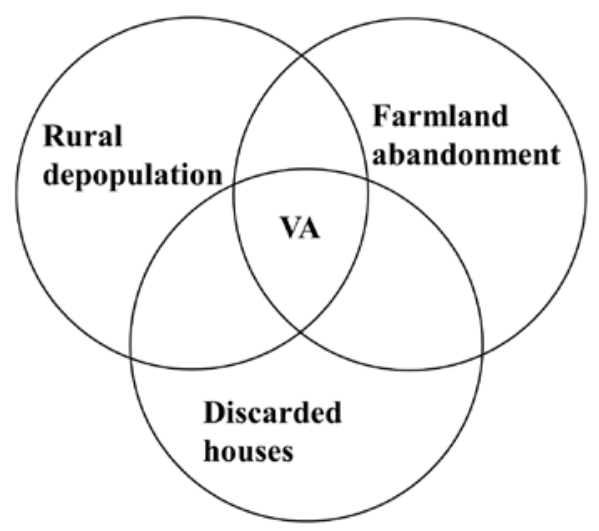

Figure 1

This article is protected by copyright. All rights reserved. 


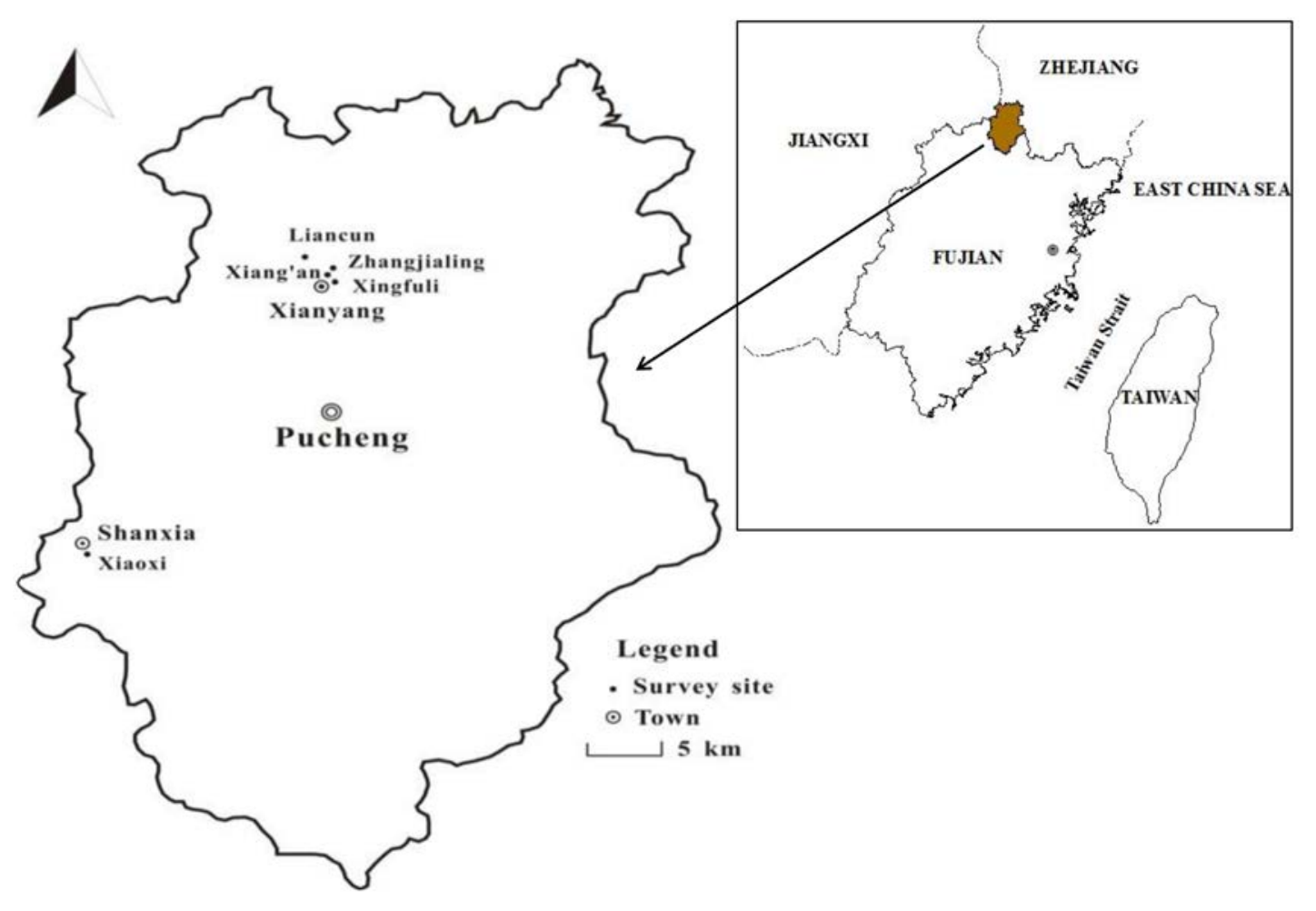

Figure 2

This article is protected by copyright. All rights reserved. 


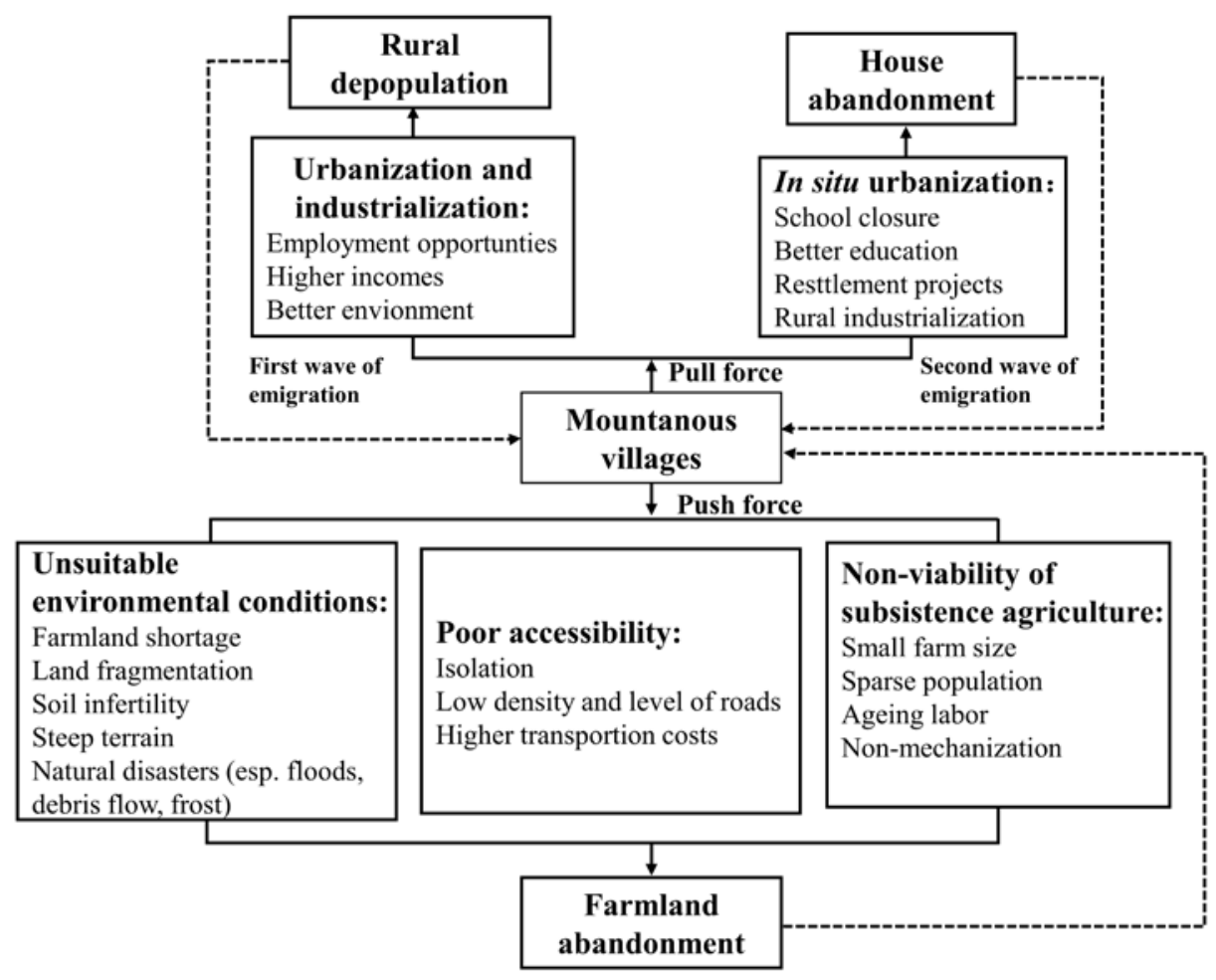

Figure 3 


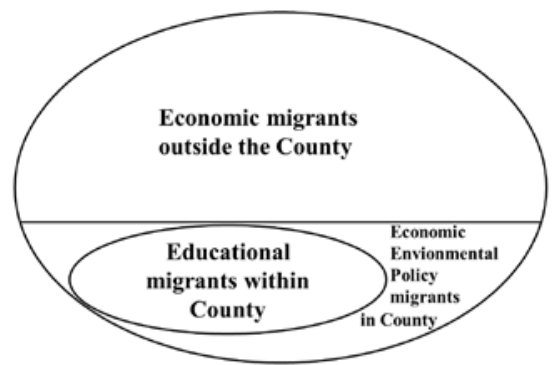

Figure 4

This article is protected by copyright. All rights reserved. 


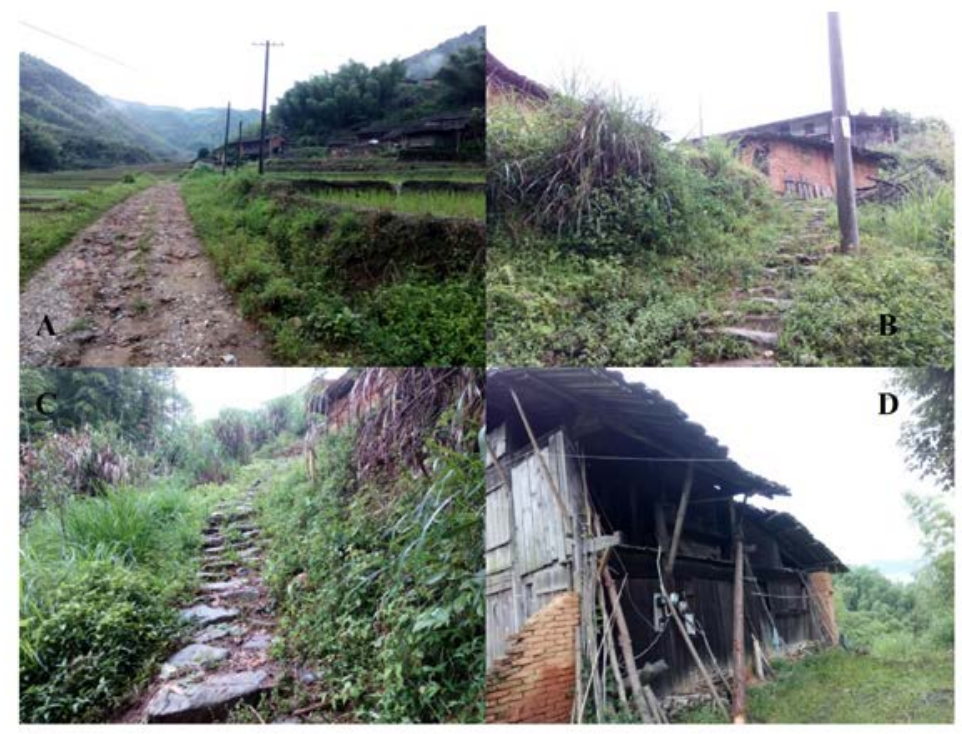

Figure 5

This article is protected by copyright. All rights reserved. 


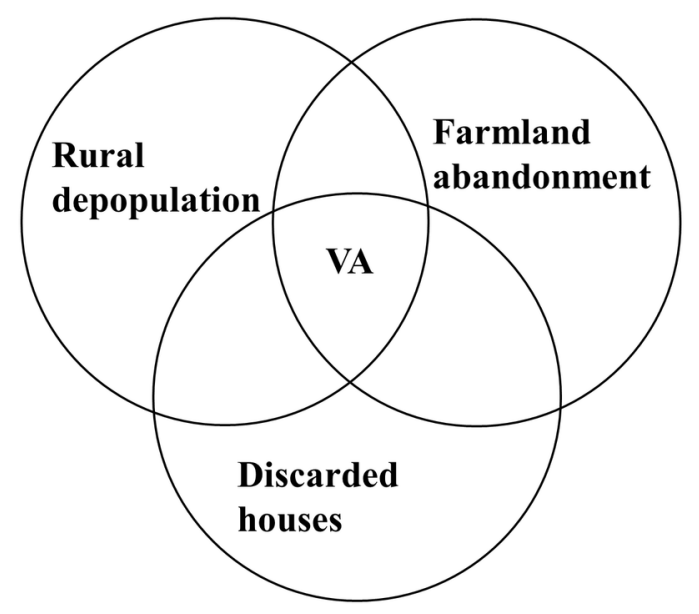

LDR_3303_F1.tif

This article is protected by copyright. All rights reserved. 


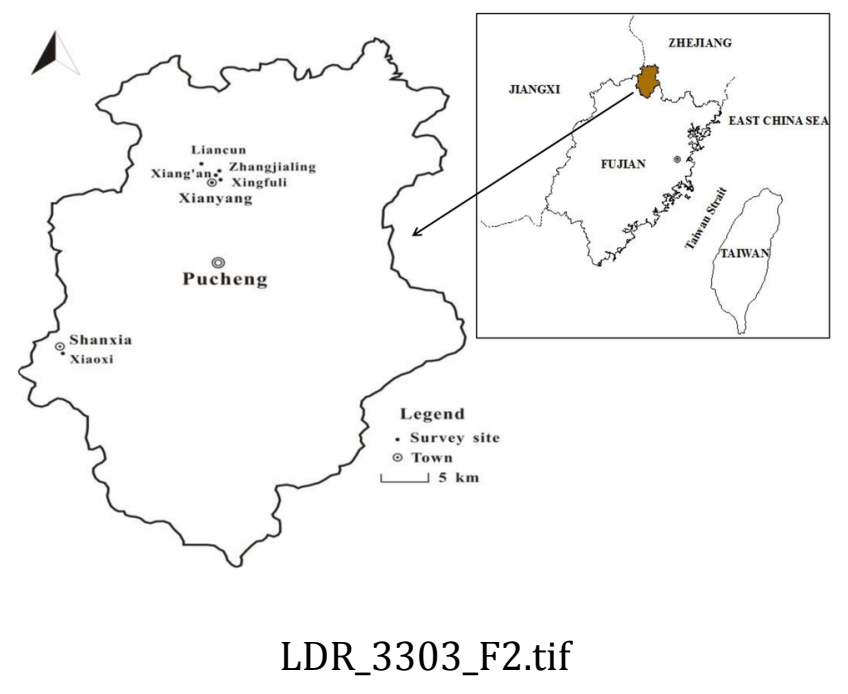

This article is protected by copyright. All rights reserved. 


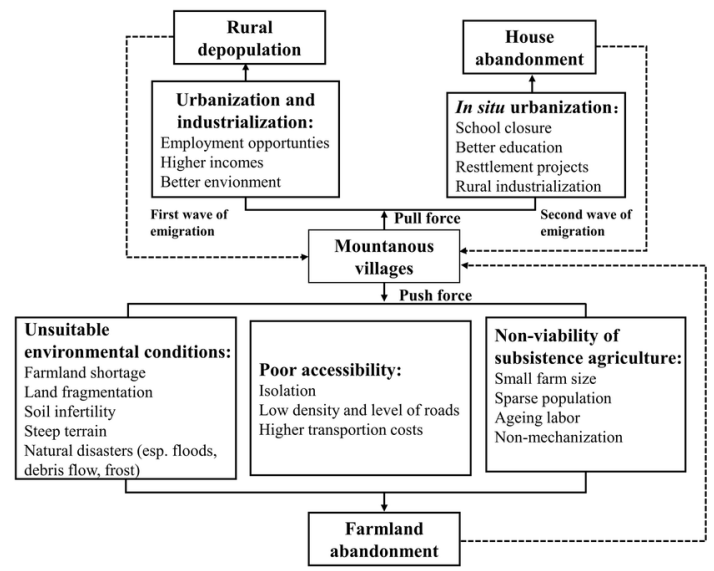

LDR_3303_F3.tif

This article is protected by copyright. All rights reserved. 


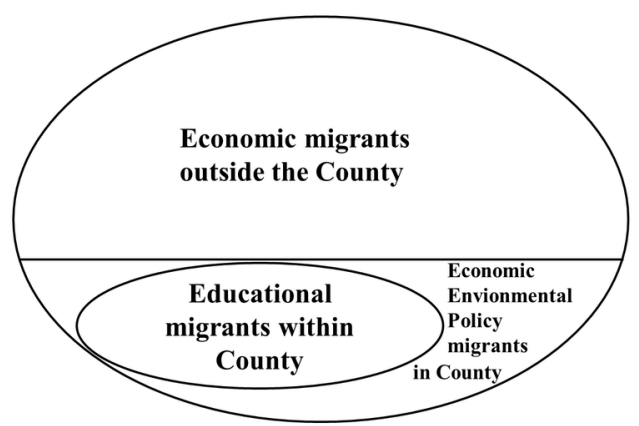

LDR_3303_F4.tif

This article is protected by copyright. All rights reserved. 


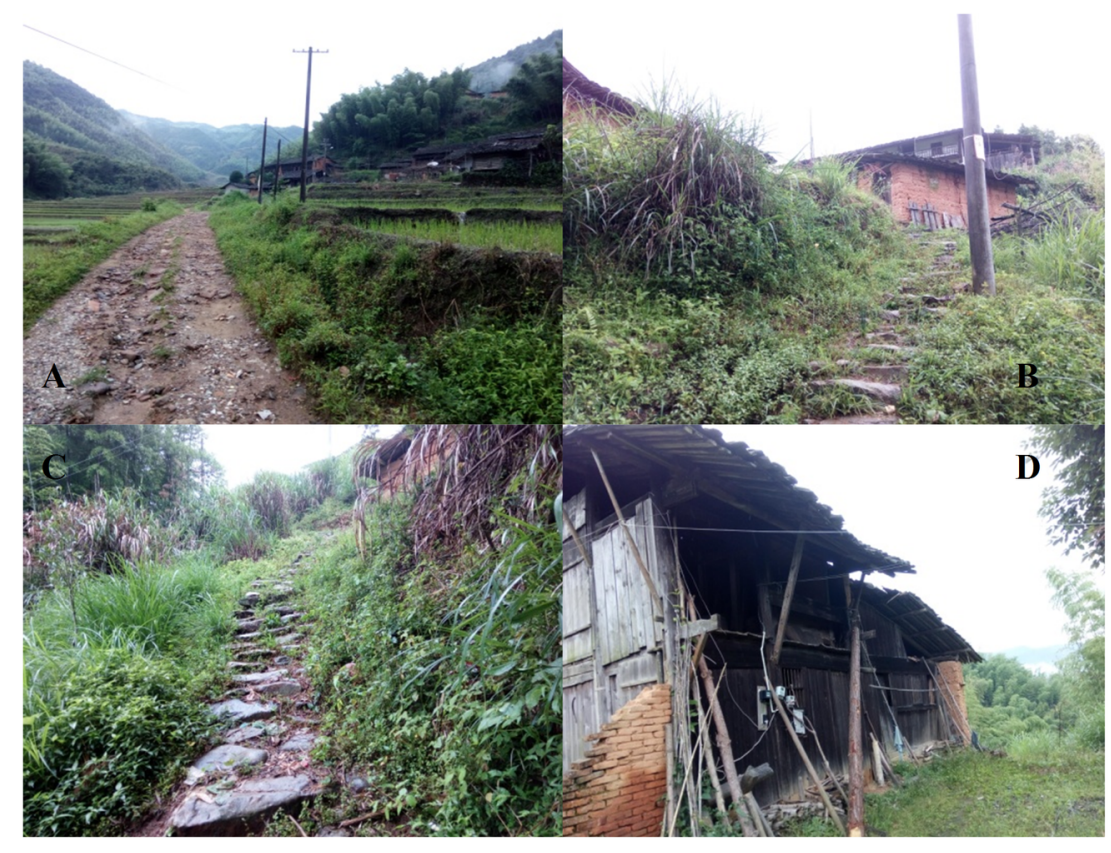

LDR_3303_F5.tif

This article is protected by copyright. All rights reserved. 


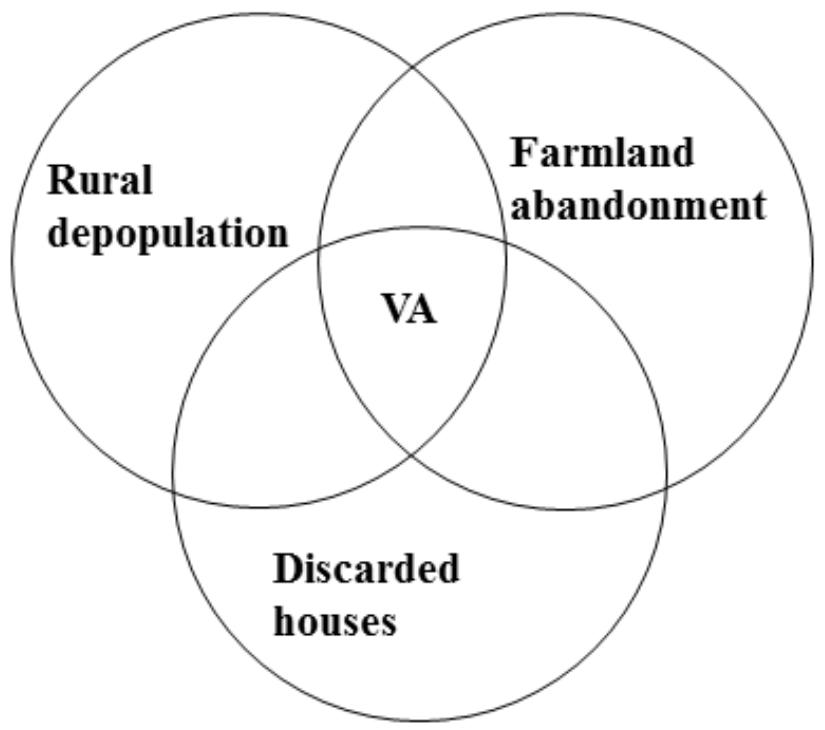

This article is protected by copyright. All rights reserved. 


\section{Figure 2 would be provided separately}




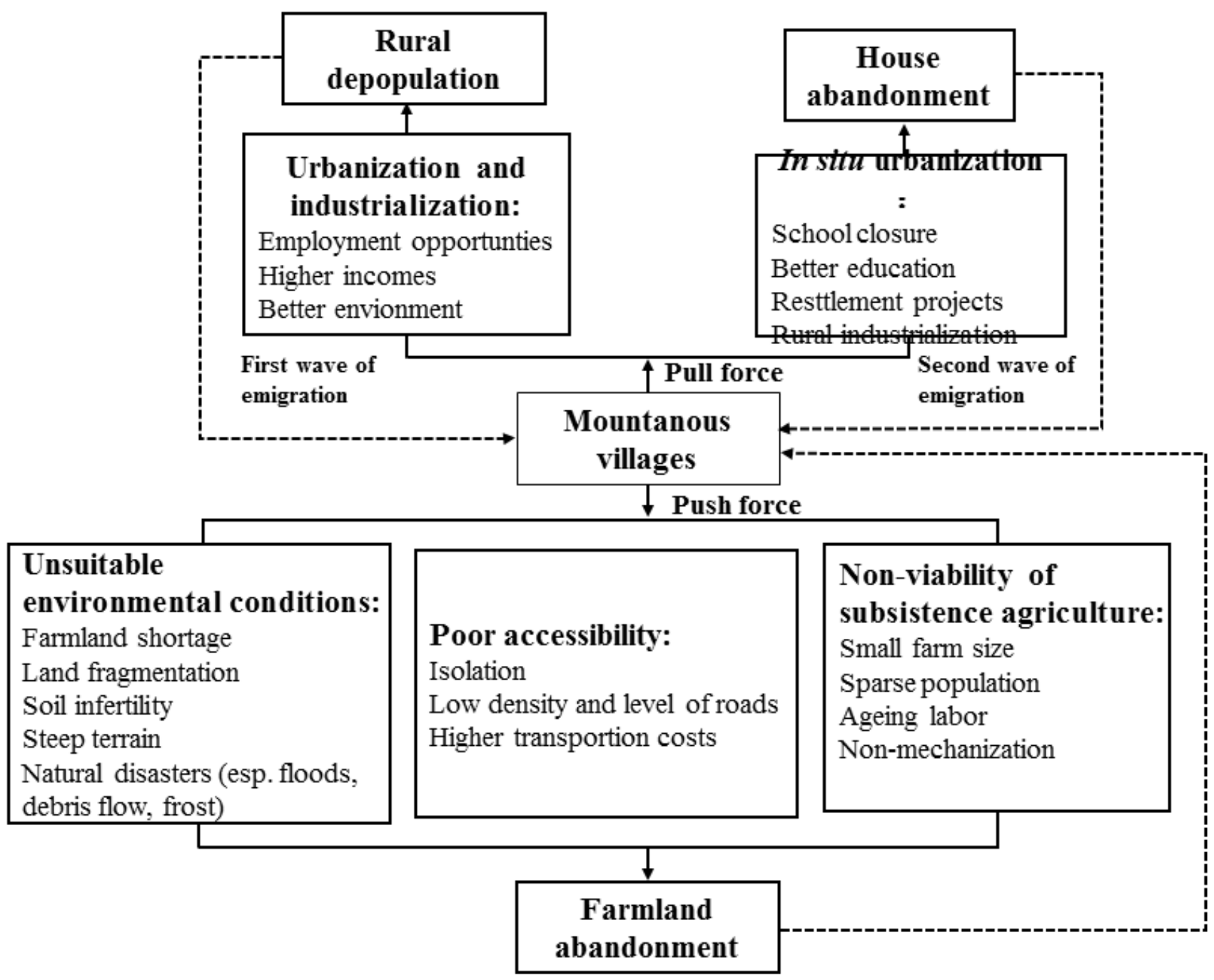

This article is protected by copyright. All rights reserved. 


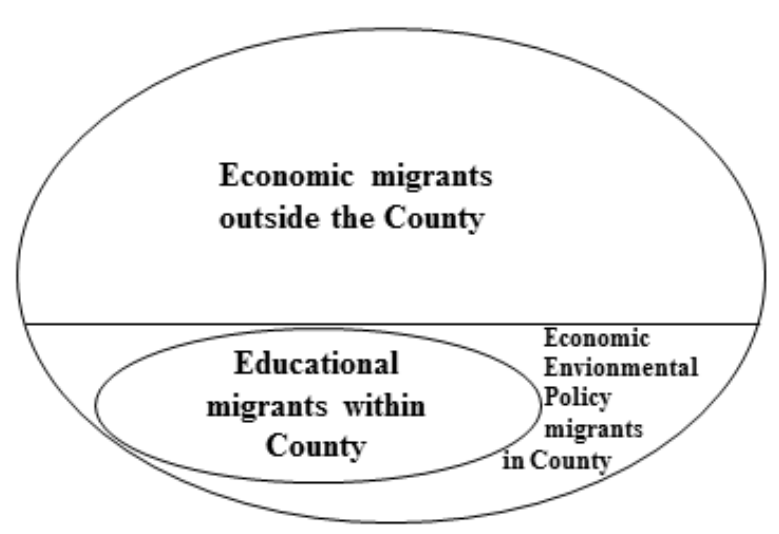

This article is protected by copyright. All rights reserved. 


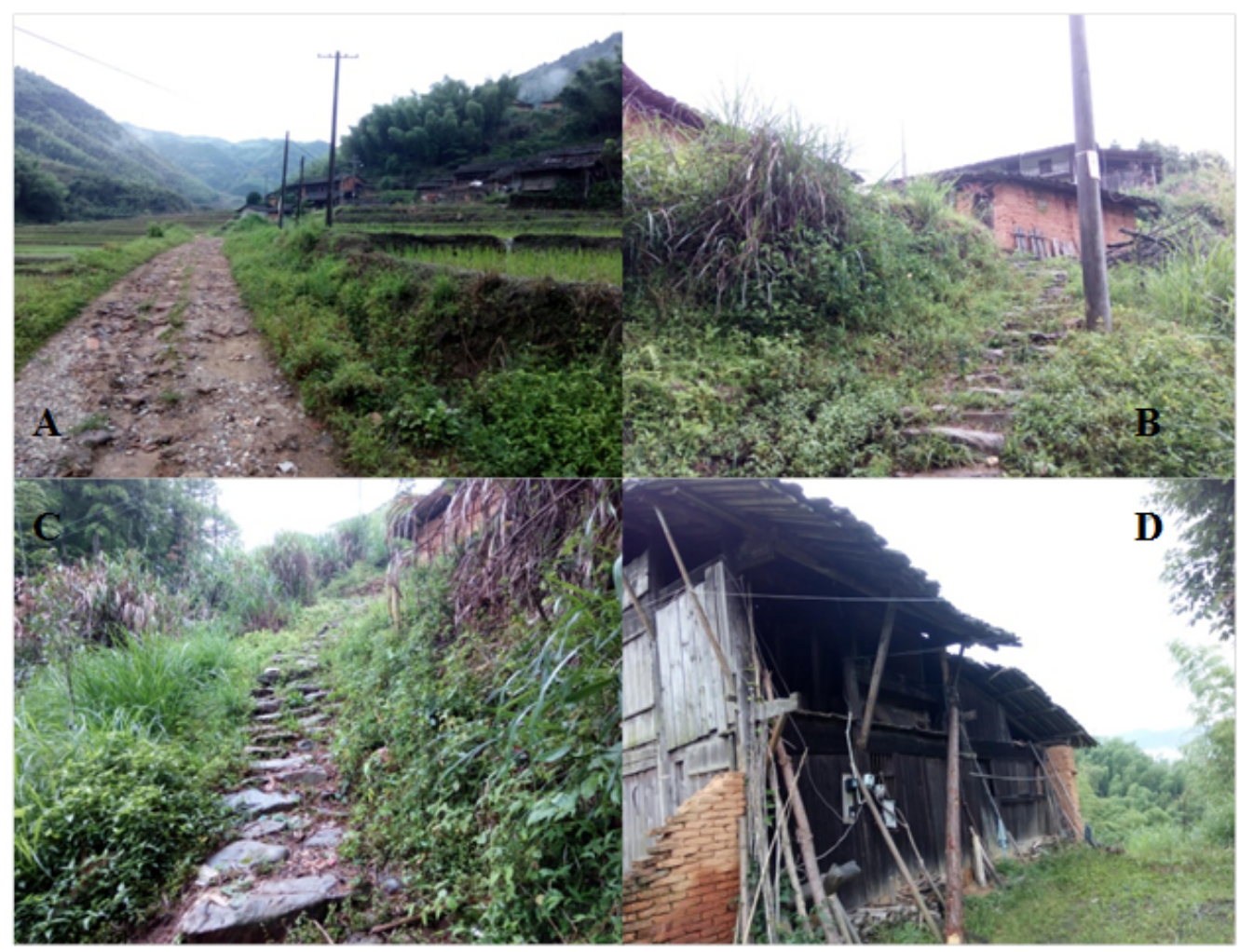

This article is protected by copyright. All rights reserved. 


\section{University Library}

\section{- M M N E R VA A gateway to Melbourne's research publications}

Minerva Access is the Institutional Repository of The University of Melbourne

Author/s:

Wang, C;Zhang, Y;Yang, Y;Yang, Q;Hong, J

Title:

What is driving the abandonment of villages in the mountains of Southeast China?

Date:

2019-06-01

Citation:

Wang, C., Zhang, Y., Yang, Y., Yang, Q. \& Hong, J. (2019). What is driving the abandonment of villages in the mountains of Southeast China?. LAND DEGRADATION \& DEVELOPMENT, 30 (10), pp.1183-1192. https://doi.org/10.1002/ldr.3303.

Persistent Link:

http://hdl.handle.net/11343/285751 